University of Minnesota Morris Digital Well

University of Minnesota Morris Digital Well

2016

\title{
Prefacing Texts, Authorizing Authors, and Constructing Selves: the Preface as Autobiographical Space
}

Julie A. Eckerle

University of Minnesota - Morris, ecker014@morris.umn.edu

Follow this and additional works at: https://digitalcommons.morris.umn.edu/eng_facpubs

Part of the Literature in English, British Isles Commons

\section{Recommended Citation}

Eckerle, Julie A. "Prefacing Texts, Authorizing Authors, and Constructing Selves: the Preface as Autobiographical Space." In Genre and Women's Life Writing in Early Modern England. London: Routledge, 2016.

This Book Chapter is brought to you for free and open access by the Faculty and Staff Scholarship at University of Minnesota Morris Digital Well. It has been accepted for inclusion in English Publications by an authorized administrator of University of Minnesota Morris Digital Well. For more information, please contact skulann@morris.umn.edu. 


\title{
Chapter 7
}

\section{Prefacing Texts, Authorizing Authors, and Constructing Selves: The Preface as Autobiographical Space}

\author{
Julie A. Eckerle
}

The preface is a unique textual space, one that demands a very particular kind of rhetoric because of its generic constraints and yet allows ample room for an author's manipulation and creativity. ${ }^{1}$ Perhaps the best articulation of the preface's paradoxical nature appears in Barbara Johnson's playful response to Jacque Derrida's Dissemination. In her translation of Derrida's text, Johnson extends the first essay's brief title- "Hors livre, préfaces" (literally, "outside the book") - by adding a list of potential synonyms: "OUTWORK," "HORS D'OEUVRE," "EXTRATEXT," "FOREPLAY," "BOOKEND," "FACING," and finally, "PREFACING."2 This textual proliferation, which Johnson explains as an effort "to conjugate out some of the ramifications of this 'title' and to open Dissemination with a kind of miniaturized version of its strange textual logic,"3 also usefully highlights the preface's existence at the margins of texts and meaning and identifies the preface of a published text as an odd, perhaps undefinable, space. Indeed, as something "extra" or "outside," a preface suggests its own disposability and lack of direct impact on the primary text. As something "pre" text, the preface suggests a space or time that has already been superseded by the text it once foreshadowed. As "foreplay," it is potentially tantalizing and provocative but quickly outdone by the force of the primary text.

And yet, significantly, this odd space on the margins of the printed word has a culturally sanctioned position within the textual world, containing within its history a range of foundational examples from Cicero to Dante and an extensive amount of theoretical discussion, especially in classical treatises on rhetoric. The preface, after all, does the important work of presentation: introducing a text, praising a patron, requesting financial support, and generally "negotiat[ing] a place for the work, and its author, in the public realm." tangential to the work of the primary text and thus quickly forgotten in the transition from preface to primary text and in the shift from a self-concerned voice 
to one that is generally much less personal. Perhaps, then, it is no surprise that this strange and contradictory space should provide a place for textual experimentation and a forum for writers who are otherwise denied the right to public speech. Indeed, precisely because it is marginalized, the space of the preface becomes an acceptable place for those typically denied a voice to say those things that have no place in the privileged text. The preface allows for that which is typically not allowed, including the published voices of unsanctioned writers and, in turn, more possibilities for innovation and even personal commentary than such writers would be allowed in a primary text.

This is especially the case for women of the English early modern period who chose to write - and occasionally even publish — despite strong social pressure against such acts. These women wrote from the social margins and appropriately found a marginal space from which to enter the text. And yet, even though early modern Englishwomen's prefaces are frequently anthologized and increasingly considered as useful source material in studies of individual women writers, no published study to date has examined in any collective, comprehensive way how these women used this valuable textual space. ${ }^{5}$ In her work on French Renaissance women writers, Anne R. Larsen reveals the value of this kind of study:

Early women writers exploited the preface's "marginality" and epistolarity. To legitimize their uncommon venture, they adroitly adapted its apologetic topoi; and they heightened its sense of relational "intimacy" by framing it as a letter addressed by one woman to generally another woman friend, mentor, or patron. The preface thus occupies a strategic function in their venue into the world of the printed book in which relatively few had entered. ${ }^{6}$

This characterization of women's early use of the preface suggests the rhetorical savvy with which these writers approached a space intended primarily for apology and self-effacing explanation; it further highlights the preface's usefulness for the fledgling female author.

In this essay, I explore a few of the prefatory strategies early modern Englishwomen used - and often manipulated - in order to authorize themselves and their texts. ${ }^{7}$ In the process, I argue that the very strangeness of the prefatory space is what both attracts and enables marginalized writers like early modern women, and I note in particular how this space enables original composition, not only by introducing and making way for such work in the primary text but also, more significantly, by allowing for original argument within the preface itself. Finally, I consider how-in the process of authorizing themselves as authoring women and as women capable of authoring - early modern Englishwomen further manipulate the textual space of the preface into something intensely personal. Because women had to defend not only their authorial choices but their very identities as respectable women as well, their prefaces must be somewhat autobiographical. Here women created new identities for themselves as authors, as 
women, and as women with authority enough to enter the public arena. Thus personal details mingle with authorial justifications and even, on occasion, polemic defenses of the female sex.

Early modern prefaces not only introduce texts in a range of genres, but they also take a number of different forms themselves, including general prefaces to the reader, dedicatory epistles and verses addressed to individual personages, and prefatory poems like Rachel Speght's A Dreame, which precedes her Mortalities Memorandum (1621). But the prefatory strategies used by early modern women are remarkably consistent across age, generic, and - as Larsen's work suggestsnational boundaries even as they wrote with different purposes and different styles. In particular, these women emphasized their humility and adherence to traditional female virtues, worked to create an ideal (that is, sympathetic) reader for their works, attempted to forge bonds with these readers that would prohibit rejection of their major claims, and provided the necessary personal information to accomplish all of these goals. Because the burden on their prefaces was intense, requiring them to accomplish traditional prefatory tasks as well as those specific to a female author, such as establishing an authorial voice and creating a space for women writers in general, early modern women relied on sophisticated rhetorical maneuvering to structure their prefatory remarks. This suggests that most early modern women writers recognized the value of the preface and exploited it for their own benefit, often to make arguments in defense of women that have no place in the primary texts but that, paradoxically, create the space in which those texts can be written.

Many of the techniques traditionally associated with the preface actually assisted the woman venturing into print. For example, the preface as a genre was designed to put its readership in the right frame of mind for persuasion and thus demanded justification for a variety of authorial choices. As Wendy Wall notes in The Imprint of Gender: Authorship and Publication in the English Renaissance, extensive prefatory disclaimers were especially necessary in the new print world of early modern England, since "writers both male and female risked estrangement from the social sources of power when they chose to publish. Because print publication was rhetorically scripted as a lower-class activity, writers of both genders had to counter the force of this stigma." ${ }^{8}$ But for women the stakes were even higher, in part because of the gendered rhetoric of authorship that Wall traces so effectively in her work. "If women were tropes necessary to the process of writing," Wall asks, "if they were constructed within genres as figures for male desire, with what authority could they publish? How could a woman become an author if she was the 'other' against whom 'authors' differentiated themselves?"10 In other words, the obstacles facing women who wished to publish, combined with both traditional and then-contemporary needs for authorial disclaimers, meant that women writers simply had to explain themselves in order to create an audience 
receptive to their (that is, women's) work. That apology was already written intoand thus expected of - the genre of the preface proved especially useful for these women.

Among other things, women writers often had to defend their choice of genre and almost always explained their decision to be "authorial" in the first place. Thus Margaret Tyler uses the prefatory space of her 1578 translation of the first part of Diego Ortunez de Calahorra's The Mirrour of Princely Deedes and Knighthood (a Spanish romance) in part to explain why she chose to translate and publish such questionable material. After all, even though translation was an acceptable venue for women's texts at this time, secular topics were generally not, and it is telling that, as Mary Ellen Lamb notes, "no other woman published a translation of a romance in [the sixteenth] century!" 11 Tyler's choice of genre violated injunctions against women reading romances, much less translating them. Therefore, in both her traditional dedication to Lord Thomas Howard and the more polemic "M.T. to the Reader" that follows it, Tyler defends her choice of this particular romance on the basis of its instructional value and delightful style: "it is done into English," she says in true Horatian fashion, "for thy profit and delight" (Aiiir). ${ }^{12}$ The instruction comes through the characters' exemplary demonstration of "magnanimitie and courage," especially on the battlefield, while the delight comes from "the varietie and continual shift of fresh matter" (Aiiir). ${ }^{13}$ Tyler is not at all bothered by the fact that her material is "more manlike than becometh my sex"; on the contrary, she rather sarcastically notes "that it is not necessary for every trumpeter or drumster in the warre to be a good fighter: they take wage onely to incite others" (Aiiir). Further, she cites a benefit for both male and female readers: "be it that the attempt were bold to intermeddle in armes, ... yet to report of armes is not so odious but that it may be borne withal, not onely in you men which your selves are fighters, but in us women, to whom the benefit in equal part apperteineth of your victories" (Aiiiv). And yet, despite such bold argumentation on the part of a woman who has dared to translate and publish a romance, Tyler simultaneously explains away her actions and seeming "choices" via a commonplace prefatory disclaimer: others encouraged her to both translate and publish, and even the choice of material was not her own. As she explains to Howard in the epistle dedicatory, "the matter was offered not made choice of, as ther appeared lykewise little lybertie in my first yielding" (Aiir). Tyler's example is useful because it demonstrates how a female writer could use prefatory explanations to her benefit, justifying even the publication of romance material through concern for her readers (what will both benefit and delight them) and through laudable female obedience. In other words, Tyler walks the fine line between the authorial assertion necessary to see a work through to its publication and the female humility that was seen as the hallmark of a respectable woman.

Perhaps it is not surprising, then, that female writers' prefatorial defenses of authorship often extended beyond individualized explanations to general defenses of women writers. This is where Tyler's preface to her readers becomes especially 
bold and straightforward. Her oft-quoted argument is based on the fact that women are common dedicatees (and thus, she assumes, readers) of men's work. Therefore, she says, there is nothing wrong with women writing as well: "it is all one," she explains, "for a woman to pen a story, as for a man to addresse his story to a woman" (Aiiiiv). In Aemilia Lanyer's "To the Vertuous Reader," which prefaces her Salve Deus Rex Judaeorum (1611), Lanyer claims that her primary purpose in the work is "to make knowne to the world, that all women deserve not to be blamed" (48) even though both men and other women have slandered the female sex. ${ }^{14}$ In the course of her preface, and later in the title poem, Lanyer summons numerous female Biblical figures as evidence for her claims in women's defense. Other women are more humble, though equally invested in the need to defend women and their textual ventures. Anne Wheathill, for example, makes a case for writing as a wise use of a woman's time, since it helps her avoid idleness; Wheathill explains that the prayers she has collected "to the advancement of Gods glorie" (A3r) in her 1584 collection of private prayers, A Handfull of Holesome (though Homelie) Hearbs, will also act as "a testimoniall to the world, how I have and doo (I praise God) bestowe the pretious treasure of time, even now in the state of my virginitie or maidenhood (A2r)." ${ }^{15}$ A very personal statement like Wheathill's works in two ways: it first serves to explain her own authorial choices, and it secondarily suggests that, rather than being incompatible, writing and female virtue might actually support and enable one another. In other words, it is through and in her writing that Wheathill is able to make the most productive use of her time as a virtuous Christian woman. ${ }^{16}$ Both suggestions help to assuage readers' likely concerns and thus, in true prefatorial fashion, put them in the right frame of mind for further reading.

Such elaborate justifications would not work, however, if early modern women writers did not also make use of the most basic and perhaps most important of all traditional prefatory gestures: the humility topos. This technique tended to manifest itself in a series of disingenuous disclaimers, such as the commonplace "reluctance to appear in print," 17 but was absolutely crucial for women who wished to speak (and be heard) without being held unchaste. Indications of humility are thus pervasive in women's prefaces, ranging from the consistently humble tone used by Tyler in her dedicatory epistle to Wheathill's seemingly casual reference to "the weakenes of my knowledge and capacitie" (A2v). Many writers, like Anna Weamys in the prefatory apparatus to A Continuation of Sir Philip Sidney's Arcadia (1651), sign their dedicatory messages with phrases like "Your Honours devoted Servant" (109), ${ }^{18}$ and others, like Speght in her prose preface to A Mouzell for Melastomus (1617), reference their "unworthi[ness]" (3). ${ }^{19}$ None of these examples are surprising, but they enabled the project of the authoring woman by allowing her to code her authorial acts, however unorthodox and capable, as the products of humble and inferior femininity. True or not, this is what readers would want to hear, and the genre of the preface just happened to require it. 
Early modern women writers were similarly able to capitalize on the preface's traditional epistolarity, for prefatory texts are always addressed to a readerwhether known or unknown, general or specific, singular or plural-and sometimes actually take the form of an epistolary dedication. This prefatory feature created a kind of intimacy that female writers were quick to manipulate in order to maintain the appearance of traditional female virtue and behavior and to further influence the reader's response to the text. The distinct difference in tone between Tyler's self-effacing and fawning dedicatory epistle to Howard and her bolder preface to the reader is a case in point, since the epistle presents a traditional version of femininity that the preface could not, on its own, so successfully project. More often, however, women writers addressed other women as women, evoking the seemingly private space of a letter or personal dedication in what was actually a much more public realm. Lanyer's extensive, sophisticated, and self-serving prefatory apparatus for Salve Deus Rex Judaeorum offers a familiar example here. In addition to "To the Vertuous Reader," Lanyer prefaces her poetic meditation on Christ's passion with a poem dedicated "To all virtuous Ladies in generall" and several other verse and prose dedications to the most important women of her day. Whether a blatant bid for patronage, an expression of genuine respect and/or gratitude, or - most likely - a combination of the two, Lanyer's prefatory apparatus summons "a community of good women" ${ }^{20}$ to attend to and support her poetic project via personal, individualized invitations. The benefits of this gesture are significant. As Susanne Woods explains in her introduction to The Poems of Aemilia Lanyer, Lanyer's extensive use of dedications allows her to simultaneously acknowledge and overcome her doubly unauthorized position as a lower-born, female poet: "By collapsing her unworthiness as a woman into the general unworthiness all poets must acknowledge in their dedications to the high born, she renders the happenstance of gender as visible as, and as ultimately inconsequential as, the male poet's happenstance of birth." ${ }^{21}$ The dedications also enhance Lanyer's defense of women in her subsequent poems, since - through her gender - she "claim[s] a special identity with her dedicatees, and ... allow[s] their dignity and high birth to assert the dignity and merit of all women." 22 And finally, the dedications call into being tailor-made, personal bonds with her readers that not only work to create a sense of goodwill but also make more likely a generous, supportive, and positive response to her work.

The prose dedication with which Speght begins her Mortalities Memorandum offers an example of how a writer could use even a personal, seemingly more intimate dedication to meet multiple prefatory goals or needs. Speght dedicates her text, a meditation on death, to her godmother, Marie Moundford; this forum allows Speght to praise and flatter her addressee, as all such dedications do, as she expresses gratitude for Moundford's love and affection "ever since my beeing" (46).$^{23}$ However, through the pretense of explaining her work to her godmother, Speght is also able to introduce justifications for her decision to publish and other motives beyond the selfless desire to provide "a testimonie of my true 
thankefulnesse for [Moundford's] fruitfull love" (46). Thus we learn that Speght also acts out of a "desire of common benefit" (45) and out of a much more selfconcerned desire to prove herself to her critics: "I am now, as by a strong motive induced (for my rights sake) to produce and divulge this off-spring of my indevour, to prove them further futurely who have formerly deprived me of my due" (45). ${ }^{24}$ As with many prefaces, explanations proliferate and often seem to contradict one another as the writer fulfills the required humble persona and simultaneously offers an authorial self, one that is by its very nature the opposite of humble. But the form of a personal letter is particularly conducive for this paradoxical gesture, especially when the writer is a woman and women were generally encouraged to live private, rather than public, lives. Of course, many women violated this cultural ideal, though perhaps not so blatantly as Speght, who became the first selfidentified female participant in the Jacobean pamphlet debate about women with her first publication, A Mouzell for Melastomus. But all published women writers "went public" to a certain extent, and using a traditionally personal form like a letter to introduce a text maintained the pretense, however momentarily, that the authoring act was not as bold as it might appear. As we have seen, the appearance of intimacy and the permission to directly address one's reader that are afforded by epistolarity helped to make the preface a metaphorical bridge between private life and published text, thus easing the woman writer's transition from one world to the next.

Indeed, as I have argued throughout this essay, the reader-oriented approach demanded by the preface - and exemplified by such techniques as offering selfeffacing apologies, creating personal dedications, and consistently flattering one's readers - actually enabled early modern women's entrance into the world of print. The particular ability to create common ground with their readers was essential, for this strategy meant establishing a female community that would encompass themselves as well as their readers. As Larsen notes, this community of women essentially offered a support group. ${ }^{25}$ But I would argue that the rhetorical motivation behind the language of inclusivity is at least as important as the support group it creates, since inclusion in a group makes disagreement with the author more difficult. Readers who choose to disagree must first disassociate themselves psychologically from the group with which they have been defined. And to disassociate, they must also reject the primary ideas of the group, ideas that are portrayed in the prefaces as positive, moral, and in defense of their own sex.

This technique is closely linked to epistolary addresses but also manifests itself within the text, most obviously in the form of direct address. Tyler's audience technically includes both men and women, but she refers to her female readers with the welcoming language of "us" and her male readers with a more distant "you" (Aiiiv) ${ }^{26}$ Lanyer, too, addresses her main preface to the non-gendered "Virtuous Reader" but quickly makes it clear that her collection is intended primarily for women, noting that she intends it "for the generall use of all virtuous Ladies and Gentlewomen of this kingdome" (48). Finally, although Wheathill's 
extended title notes her book's benefit for "all such as are devoutlie disposed" (A1r), her preface speaks explicitly to "all Ladies, Gentlewomen, and others, which love true religion and vertue, and be devoutlie disposed" (A2r). Significantly, she here relegates men to the "other" category.

More importantly, however, all three of these women use inclusive language to create personal links between reader and writer and between the reader and the issues at hand. Tyler and Lanyer speak of "us," women who deserve to write texts just as men do and who (in Lanyer's mind) should not heed men's unsubstantiated accusations against them, and Wheathill speaks of her supportive readers as a community of "brethren and sisters in the Lord" (A3r). Such inclusivity operates as an offer, an extended hand if you will, into a unique and valuable community. Tyler's inclusive "us" invites women into a community of female dedicatees, readers, and-according to her logic-writers, and Lanyer invites the reader to become one of many women, including Biblical heroines, who have resisted arrogant and misguided men. Similarly, one who accepts Wheathill's offer of brotherhood or sisterhood practices the very faith on which her text is based. In each case, the writers try to gain supporters by creating a bond between themselves and their readers that will be psychologically difficult to break and by offering sisterhood and fellowship to those who will read with an open mind. ${ }^{27}$

Accordingly, they explicitly place their literary success in their readers' hands, a goodwill gesture that is also rhetorically powerful. Lanyer offers her readers "all increase of virtue" in return for "their favourable and best interpretations" (50). She also distinguishes between these ideal readers and those women who "speake unadvisedly against the rest of their sexe" (48); this gesture forces her readers to align themselves with the approving crowd. Tyler similarly manipulates her readers' responses to her major claims by prefacing them with phrases like "thou knowest" (Aiiir) ${ }^{28}$ and by making her opponents' stances absurdly polarized. For example, when defending her choice of genre, she says she hopes her "ill willers ... would enforce me necessarily either not to write or to write of divinitie" (Aiiiiv). Thus she subtly keeps her readers from aligning themselves with either antagonistic position. She also suggests a reader-author pact similar to Lanyer's when she says, "and if I may deserve thy good favour by lyke labour, when the choice is mine owne I will have a speciall regard of thy liking" (Aiiiiv). According to this pattern, Wheathill also places the success of her readerly community on the nature of the readers' response. Speaking of her desire for acceptance, she says:

Which if I may obtaine, with the good judgement and liking of all my brethren and sisters in the Lord, I shall thinke my time most happilie bestowed: for that thereby I did avoid idlenes, to the pleasing of almightie God; and have gained those ... to be my freends, that shall taste these grose hearbs with me. (A3r-A3v)

In other words, only if her prayer collection is well received will she have gained a spiritual community of fellow believers and spent her time wisely. Fortunately, 
she has stacked the deck in her favor by claiming God's support of her work throughout the preface, trusting that He will find it "no lesse acceptable" (A3r) than that of more learned individuals. Assuming that God does indeed accept her work, Wheathill makes it difficult for her Christian readers to do otherwise.

In these skillful appeals to their readers, early modern women blend many traditional prefatory techniques in a way that is ideally suited to their needs as female authors. In the rest of this essay, I will turn to a more surprising but equally important element of early modern Englishwomen's prefaces: the extraordinary amount of personal information that these writers offer in the attempt to both appear duly humble and effectively justify their violation of social codes. Certainly, the preface of a published text is the natural place for personal information, if it is to be included at all. However, as in so many cases, this gesture is particularly tricky for women. Given the early modern ideological formulations that equated women's sexual and verbal excesses-thus suggesting that the female speaker orally exposed herself when she spoke publicly—sharing personal details in a public forum was especially problematic. According to this logic, the female writer who participates in autobiography makes her very person into a text, symbolically offering her body for public perusal. Not surprisingly, therefore, none of the personal tidbits provided by early modern Englishwomen in their prefaces has the "exposé" quality expected by readers of twenty-first century autobiography. ${ }^{29}$ On the contrary, the details are mundane and superficial, rarely moving beyond references to age, family, or the particular moment that lead to the writing act.

Nonetheless, such personal references are noteworthy, for they demonstrate how an acknowledgement of self - and especially of gender - was commensurate with an early modern woman's foray into public authorship even as she tried to be as self-effacing as possible. Yes, there are instances of a woman's attempt to explicitly hide her gender and/or identity, including the publication of $A$ Continuation by "A. W." rather than "Anna Weamys" ${ }^{30}$ and the likely use of pseudonyms by female participants in the early seventeenth-century pamphlet debates. But even the denial of gender is an acknowledgement of its importance, and - in the case of Weamys's Continuation - the commendatory poems prefixed to the romance acknowledge the author's female identity even if she is not named directly.

In addition to the fact that they are women, we learn from their prefatory material that Tyler is of a "staied age" (Aiiiiv) ${ }^{31}$ and in need of money to pay her debts; ${ }^{32}$ that Wheathill is an unmarried virgin who claims to lack formal education; that Speght is a young but educated woman (and an experienced author by the time she writes Mortalities Memorandum); and that Margaret Ascham, who dedicates her husband's The Schoolmaster to Sir William Cecil in 1570, is a widow with many orphans. ${ }^{33}$ Beyond such details - which also make clear that the early modern female writer fit no single profile - we learn about the writers' intellectual identities. Tyler, for instance, finds great delight in reading Calahorra's romance 
and seems to value its style - "the reporters device"-more than its content or verity - "the truth of this report" (Aiiir). ${ }^{34}$ Such revelations contribute to her insistence on the text's value for readers, but they also work, quite usefully, to deflect any concern that she immerses herself in romance for the morally suspect material, as was so often thought to be the reason for-and the primary danger of - a woman reading romance. At the other end of the spectrum, Wheathill's selfpresentation as an uneducated but zealous Christian woman both justifies her decision to write and underscores her work's status as the inspired-and thus acceptable - product of a woman's spiritual devotion rather than the intellectual product of an unacceptable program of female education. Similarly, Weamys's acknowledgement of her admiration for Philip Sidney's work serves to counter suspicions that she is so ambitious as to think she can match him. On the contrary, as is so often the case in prefaces by both men and women (as already seen with Tyler), "someone else" made her do it. As she says to her dedicatees, "my ambition was not raised to so high a pitch, as the Title now manifests it to be, until I received Commands from those that cannot be disobeyed" (109). Her disclaimers put her intellectual work safely in the realm of obedience and overshadow the fact that she has not only read and admired but thoroughly absorbed Sidney's romance.

Perhaps the most complicated of the examples I offer here is Speght, for her written work - especially the thinly veiled A Dreame - reveals rhetorical finesse, a sharp wit, and even a bit of the heroic in the tone and manner with which she presents herself. In this prefatory poem, Speght traces her female speaker's quest for knowledge, a quest that takes place in the safe-because otherworldly-realm of a dream. Yet the text is clearly autobiographical, referencing Speght's general intellectual leanings, her participation in the pamphlet debate initiated by Joseph Swetnam's misogynist diatribe, and her mother's death. The narration poignantly describes how empty and sad the speaker feels as a result of Ignorance, how she eventually comes to believe that her desire for Knowledge is "a lawfull avarice" (231), and how - despite the fact that "some occurrence" (234) ends her pursuit of knowledge, she nonetheless takes up the pen when duty calls. Thus she heroically attempts to save women by using her Mouzell "to binde [Swetnam's] chaps" (246) and writes Mortalities Memorandum to expose the cruel nature of the ultimate villain, Death. Like so many other preface writers, she claims that her text will benefit her readers:

I'le blaze the nature of this mortall foe,

And shew how it to tyranize begun.

The sequell then with judgement view aright,

The profit may and will the paines requite. (297-300)

Through this heroic characterization of her textual efforts, Speght both explains herself and defends all women, gestures we have come to expect. And though she works hard in her prefatory materials to present a self that is not learned, a self who 
is generally "defective in knowledge" ("Reader," 31) ${ }^{35}$ with a particular "insufficiency in literature" ("Virtuous Ladies," 5), ${ }^{36}$ her texts clearly convey the opposite.

The autobiographical details summarized here paradoxically depict Speght as the heroic defender of all people (but especially women) and, simultaneously, a woman who clearly knows her place. In A Dreame, she describes her return to the non-intellectual life, though this happens, ironically, before her written attack on Swetnam:

... some occurrence called me away.

And made me rest content with that I had,

Which was but little, as effect doth show;

And quenched hope for gaining any more,

For I my time must other-wayes bestow.

I therefore to that place return'd againe,

From whence I came, and where I must remaine. (234-40)

In Certain Quaeres to the Bayter of Women - a tract attached to A Mouzell for Melastomus - she says that education is, quite practically, limited to her spare time: "that little smattering in Learning which I have obtained, being only the fruit of such vacant houres, as I could spare from affaires befitting my Sex" (31). ${ }^{37}$ And in her dedicatory epistle to Mortalities Memorandum, Speght even claims to have matured from the "forward" self who printed previous works (45) to the very grateful and humble self who dedicates her work to Moundford. ${ }^{38}$

Speght's example is so unusual because, unlike most of the writers I have considered here, the autobiographical details she provides are central to her text, thus claiming a certain amount of significance. The somewhat tortured intellectual self conveyed through Speght's prefatory dream-vision poem is not built on scattered details or fragments of self-narrative that seem to exist only in order to excuse or explain an author's actions. Rather, this figure of a knowledge-hungry woman is the poem, and it stands in defiance of the more traditional apologetic self Speght also tries to project. The amount of time Speght devotes to her female dreamer, the heroic achievements of this character, and the text's bold defense of female education suggest, more than other texts can do, just how rhetorically motivated women's prefatory gestures are. Thus, like Speght, most female writers use their prefaces to humbly deny both ambition and intellectual capacity even as they reveal these very same attributes.

Furthermore, though not as boldly as Speght and in spite of their general adherence to the humility topos, early modern women writers demonstrate through their prefaces that they are quite confident and more than willing to take risks. One is, of course, the act of writing and/or publishing. Another, in many cases, is incorporating polemical defenses of women alongside more private and personal, often apologetic, disclosures. And yet another is their willingness to claim 
authority for what they are doing. For example, in Tyler's humble epistle to Howard, she nonetheless claims the right and the ability to make the best decisions about her work. After explaining how others forced her to take on the translation project, she notes that she made the decisions about the dedication: "reserving to my selfe the order for the dedication, so as I should thinke best either for the defence of my worke, or for some perticuler merite towards me. And heerein I tooke no long leysure to finde out a sufficient personage" (Aiir). Clearly this is flattery, but it is also an assertion of will. Anne Dowriche, in her dedicatory epistle to The French Historie (1589), is even more explicit: "Consider not therefore the worthinesse of the worke, but rather the will of the worker: for though the one maie justlie be condemned, yet the other deserves to be accepted" (A2r). ${ }^{39}$ Dowriche's assertion of what she deserves stands in stark contrast to the proffering of a text that its writer hopes will be accepted. And yet, Dowriche's assertion is implicit in the other prefaces I have examined here.

In fact, despite women's complete mastery of the preface's self-effacing topoi-or perhaps because of it - they reveal not only an unexpectedly powerful and confident version of themselves but also a new version of early modern women more generally. As noted above, all of the traditional prefatory elements enable self-authorization, the desired intention of any prefatory text. However, achieving this goal was especially challenging for women, who entered the text with little or no authority, especially in textual and intellectual matters. As already noted, unlike their male counterparts, women had to perform all of the traditional prefatory gestures and defend their basic right to write. Therefore, it was essential that they master the right tone (simultaneously authoritative and humble), use persuasive techniques as adroitly as possible, and never lose sight of the power of their readers. The examples offered here demonstrate that early modern Englishwomen could indeed meet all of these challenges, thus taking advantage of the prefatory space to gain the right to authorship rather than simply to describe one's authorial choices. Ironically, it is through the space of the preface and the denial of self and ability that must occur there that early modern women were able to authorize themselves - and other women - as individuals capable of authoring.

Consequently, in addition to all of its other functions, the preface can also be seen as an autobiographical, image-forging space. This is, in many ways, an obvious claim. If writers use the space to justify and otherwise explain their writerly acts, then of course they participate in a certain amount of self-fashioning, representing themselves, as needs demand, as inexperienced, reluctant, ineffective, or all of the above. The image that emerges does not have to match reality, for this is part of the prefatorial agreement between reader and writer. But for female writers, the self-fashioning was much more extensive and much less superficial and disingenuous. For the woman's greatest task-beyond explaining a variety of decisions, putting her readers in the right frame of mind, and introducing her textwas to present herself, in a convincing and socially acceptable way, as an author. Since there was no culturally designated role for an early modern woman as a 
writer, much less a published author, successfully representing herself as one would inevitably contribute to a new version of the early modern woman. When all of the humble dressing and commonplace apologies are put aside, this revised version of the female self emerges. Some characteristics of this woman - such as her devotion to God and/or family - are expected. But she is also simultaneously determined, confident, and bold; a serious thinker; and one who has mastered logic, rhetoric, and at least a few aspects of the textual landscape. She is, as Wheathill would have us believe, even more devout because of the time devoted to writing. And she is, as Speght would have us believe, no less than heroic as a result of her days in the garden of Knowledge.

In other words, the type of personal information that is provided in early modern Englishwomen's prefaces helps to forge a new conception of the woman writer at a critical moment in the development of attitudes about and towards women. Female preface writers were not only presenting new versions of themselves, though that was necessary on an individual basis in order to get written work accepted without doing too much damage to one's reputation. But they were also, collectively, presenting a new version of female subjectivity: a version that suggested humble womanhood and intellectual production were not necessarily mutually exclusive and that, over time, would pave the way for a writing woman who may still have to justify genre or subject matter but not that she was entitled to write.

As I have been arguing in this essay, the preface is the safest and most ideal space for women to perform such radical work, as their willingness to compose polemical arguments in their prefaces most dramatically suggests. Even though a few women composed original polemical tracts during this period, Speght being the most notable, women who chose not to voice their controversial opinions in such a direct way had a much more subtle route available to them in the preface. Tyler stuck to the more permissible act of translation, for example, but still managed to build arguments in defense of women writers into her preface. And Lanyer, who defends women throughout Salve Deus, is, arguably, most polemic and aggressive in its preface. Admittedly, the difference between Speght's "direct" method and the other writers' "indirect" method is one of degree, but this is precisely the value of the prefatory space. As Moira Ferguson notes, "in prefaces, writers could air their views and not be perceived as aggressive controversialists." ${ }^{40}$ These brief examples provide a sense of the kind of polemical work a rather innocent-looking document could achieve, in part because the mechanisms for such work already existed within the framework of the preface as it was used in early modern England.

Indeed, the space of the preface enabled early modern women's original composition in a number of ways. First, through its literal, physical location at the beginning of a text, a preface introduces and thus brings into being the text that follows. In many cases, as has been duly demonstrated by years of scholarship on the work of early modern women writers, this work is often more radical, 


\section{GENRE AND WOMEN'S LIFE WRITING IN EARLY MODERN ENGLAND}

subversive, or polemic than it may at first appear. Second, the preface itself allows for original thought within its marginal and thus more easily disregarded (read "less important") space. And third, the prefaces written by early modern English women contributed in a number of ways to the development and authorization of the female writer as a cultural figure. Through the defenses of women that so often found their way into prefatory material and the example offered by each woman who used this space to her advantage, additional work by women became possible.

Of course, the advent of the female writer in English literary history is complicated, based on numerous interconnected factors. But it is both likely and reasonable that the arguments made within early modern prefaces, the comfort level clearly afforded by the prefatory space, and the personae created by women in this space contributed to changes in the perception of women and what they could do that occurred around this time. For these reasons, the marginal space of the preface can be seen as a useful, though little-marked, tool in the transition from silent women to published women.

\section{Notes}

1 On the preface as a malleable generic space, see Anne R. Larsen, "Un honneste passetems': Strategies of Legitimation in French Renaissance Women's Prefaces," L'Esprit Créateur 30.4 (1990): 11-22; Kevin Dunn, Pretexts of Authority: The Rhetoric of Authorship in the Renaissance Preface (Stanford: Stanford UP, 1994); Elizabeth W. Harries, "'Out in Left Field': Charlotte Smith's Prefaces, Bourdieu's Categories, and the Public Sphere," Modern Language Quarterly 58.4 (1997): 457-73; Wendy Wall, The Imprint of Gender: Authorship and Publication in the English Renaissance (Ithaca: Cornell UP, 1993); and Catherine Gallagher, "A History of the Precedent: Rhetorics of Legitimation in Women's Writing," Critical Inquiry 26.2 (2000): 309-27. Joseph Conrad's comment to R.B. Cunninghame Graham in an 1899 letter most succinctly states the idea of the preface as its own, quite unique genre: "I am vexed about the preface. Your prefaces are so good! It is quite an art by itself." See Joseph Conrad's Letters to R.B. Cunninghame Graham, ed. C.T. Watts (Cambridge: Cambridge UP, 1969), p. 128.

2 See Jacques Derrida, Dissemination, trans. Barbara Johnson (Chicago: U of Chicago P, 1981), p. 1.

3 Barbara Johnson, translator's introduction, Dissemination, pp. vii-xxiii, edp. p. xix. Larsen's reference to Johnson in "Un honneste passetems"” directed me to this provocative piece. Indeed, my essay is indebted to Larsen's in a number of ways.

4 Larsen, p. 12.

5 Significantly, however, a number of recent dissertations indicate the increasing interest in this subject. These include, for example, Anamaria Harriette Kothe, Displaying the Muse: Print, Prologue, Poetics, and Early Modern Women Writers Published in England and Spain (Diss., U of Maryland, 1996); Amy Scott-Douglass, Prefacing the Poetess: Gender and Textual Presentation in Seventeenth-Century England (Diss., U of 
Oklahoma, 2000); and Patricia Pender, Authorial Alibis: Early Modern Women's Writing and the Limits of Literature (Diss., Stanford U, 2004.)

6 Larsen, p. 12.

7 Although there are, of course, numerous writers to whom I could refer in this essay, I have chosen only a few. My intention has been to represent as wide a range as possible of writers whose work was published in their lifetime. The writers I discuss, therefore, come from different class and religious backgrounds, have a wide range of educational experiences, write with different purposes and in different genres, and write from many different points in time within the early modern period. I have not, it should be noted, addressed Margaret Cavendish, whose prefatory writings often comment directly on both genre and the nature of her identity as a woman and a writer. In part because Cavendish is unique among early modern women writers (thus deserving more space than I could give her here) and in part because her work is amply addressed in this collection, I have decided not to include her in this essay. For an exclusive discussion of Cavendish's prefaces, see Amy Scott-Douglass, "Self-Crowned Laureatess: Towards a Critical Revaluation of Margaret Cavendish's Prefaces," Pretexts: Literary and Cultural Studies 9.1 (2000): 27-49.

8 Wall, p. 281.

9 The crux of Wall's argument is that the concept of literary authority that developed during the transition from manuscript to print culture in Renaissance England was intensely masculine and reliant on the idea of a feminine text, thereby shifting attention from the social crisis created by publication to issues of gender. Since this conception of literary authority posed even more challenges for female writers, Wall considers women's approaches to self-authorization in chapter 5.

10 Wall, p. 282.

11 Mary Ellen Lamb, "The Cooke Sisters: Attitudes toward Learned Women in the Renaissance," Silent But for the Word: Tudor Women as Patrons, Translators, and Writers of Religious Works, ed. Margaret Patterson Hannay (Kent: Kent State UP, 1985), pp. 107-25, esp. p. 115.

12 Margaret Tyler, "M.T. to the Reader," The Mirrour of Princely deedes and Knighthood, The Early Modern Englishwoman: A Facsimile Library of Essential Works, part 1, vol. 8, comp. Kathryn Coad (Aldershot: Scolar, 1996), Aiiir-Aiiiiv. All subsequent references to Tyler's preface and her dedicatory epistle, "To the right honourable the Lord Thomas Howard," are to this edition. I have modernized the spelling slightly for greater clarity.

13 Tyler, "M.T. to the Reader." Similarly, in the dedicatory epistle, she writes that the romance is "not in deede the most profitablest, as entreting of arms, nor yet altogether fruitlesse, if example may serve, as being historicall, but the while, either to be born withal for the delight, or not to be refused for the strangeness" (Aiir.).

14 Aemilia Lanyer, "To the Vertuous Reader," The Poems of Aemilia Lanyer: Salve Deus Rex Judceorum, ed. Susanne Woods (New York: Oxford UP, 1993), pp. 48-50. All subsequent references are to this edition.

15 All references to Wheathill's text are to the electronic edition, Anne Wheathill, "To all Ladies, Gentlewomen, and others," A Handful of Wholesome (Though Homely) Herbs, London, 1584, Renaissance Women Online, Women Writers Project, Brown University, 29 June $2005<$ www.wwp.brown.edu/texts/wroentry.html>. Although little is known of Wheathill, she was clearly of the Protestant faith, and her collection of prayers "is 


\section{GENRE AND WOMEN'S LIFE WRITING IN EARLY MODERN ENGLAND}

completely within the tradition of Reformed books for private devotion." See Elaine V. Beilin, Redeeming Eve: Women Writers of the English Renaissance (Princeton: Princeton UP, 1987), p. 53.

16 I am grateful to Michelle M. Dowd for helping me to clarify this and other critical points.

17 Wall, p. 1.

18 All references to Weamys are to "To the two unparalleld Sisters" in the reprint edition in Anna Weamys, A Continuation of Sir Philip Sidney's “Arcadia," ed. Patrick Colborn Cullen (New York: Oxford UP, 1994), p. 109. Cullen (introduction, pp. xvii-xi, esp. pp. xvii-xviii) convincingly explains why the "A.W" who signs the dedication and whose initials appear on the title page is thought to be Weamys.

19 Rachel Speght, "To all virtuous Ladies Honourable or Worshipfull," The Polemics and Poems of Rachel Speght, ed. Barbara Kiefer Lewalski (New York: Oxford UP, 1996). Additional preliminary materials for $A$ Mouzell include a poem and a second prose preface, both addressed to Joseph Swetnam. All references to Speght are to this edition.

20 Susanne Woods, introduction, The Poems of Aemilia Lanyer: Salve Deus Rex Judceorum, ed. Susanne Woods, pp. xv-xlii, esp. p. xxi. Woods also refers to this group as "a community of intellectual women" (xxi), an important characterization given the rewriting of female identity that occurs in the preface space, and notes, "there is no comparable work of sustained and exclusive dedication to women patrons" (xxxii). For a useful counter-argument to Woods and others who emphasize community over patronage in their reading of Lanyer's prefaces, see Mary Ellen Lamb, "Patronage and Class in Aemilia Lanyer's Salve Deus Rex Judaeorum," Women, Writing, and the Reproduction of Culture in Tudor and Stuart Britain, ed. Mary E. Burke, Jane Donawerth, Linda L. Dove, and Karen Nelson (Syracuse: Syracuse UP, 2000): pp. 3857.

21 Woods, p. xxxiii.

22 Ibid., xxxiii.

23 Speght, "To the Worshipfull and Vertuous Gentlewoman," pp. 45-6.

24 Speght here refers to her 1617 publication of $A$ Mouzell, which was apparently attributed to her father by some who could not or did not accept a woman's authorship.

25 Larsen, pp. 17-18.

26 Tyler, "M.T. to the Reader."

27 Direct addresses to men could, of course, be equally manipulative, as Tyler once again demonstrates. In her dedication to Howard, she explains that she has chosen him as her dedicatee because of the "manifolde benefits" (Aiir) she received from his parents and her gratitude for their kindnesses. However, in addition to being "a simple testimony of [her] good will" (Aiiv) toward Howard and his family, Tyler's translation is also in need of a protector. Her description of her expectations in this regard exude a not-so-subtle pressure for Howard to live up to his family's reputation:

Under your honours protection I shal lesse fear the assalt of the envious, and of your honours good acceptacion I have some hope in the mildenes of your Lordships nature, not doubting but that as your Lordshippe hath given no small signification in this your noble youth of wisedome and courage to so many as knowe you, it being the only support of your auncestours lyne: so the same lykewise will maynteine your auncestours glorye and the hope of your owne vertues with affability and gentlenesse, which was the proper commendation of your parents. (Aiiv) 
28 Tyler, "M.T. to the Reader."

29 The complexity of early modern women writing autobiographical texts for publication likely also helps to explain why most of the writers addressed in this collection produced either manuscript texts (thus avoiding publication of their "selves" altogether) or works within "safe" genres like the mother's manual.

30 See note 18 above.

31 Tyler, "M.T. to the Reader."

32 Tyler, "To the right honourable the Lord Thomas Howard."

33 Margaret Ascham wrote a dedicatory epistle to Sir William Cecil to accompany her late husband's The Schoolmaster (1570).

34 Tyler, "M.T. to the Reader."

35 Speght, "To the Reader," Certain Quaeres, pp. 31-32.

36 Speght, "To all virtuous Ladies Honourable or Worshipfull."

37 Speght, "To the Reader."

38 Speght, "To the Worshipfull and Vertuous Gentlewoman."

39 Anne Dowriche, "To the right worshipfull her loving Bro. Master Pearse Edgecombe," The French Historie, London, 1589, Renaissance Women Online, Women Writers Project, Brown University, 29 June $2005<$ www.wwp.brown.edu/text/wroentry.html>.

40 Moira Ferguson, First Feminists: British Women Writers 1578-1799, ed. Ferguson (Bloomington: Indiana UP, 1985), p. 51, emphasis added. 